Ege Tıp Dergisi / Ege Journal of Medicine 2018;57(1):46-50

\title{
Bir mevsimsel influenza epidemisi deneyimi
}

\section{Experience of a seasonal influenza epidemic}

\author{
Bedia Mutay Suntur ${ }^{1} \quad$ Hava Kaya $^{1} \quad$ Ferit Kuşcu $^{2}$
}

${ }^{1}$ Adana Numune Eğitim ve Araştırma Hastanesi, Enfeksiyon Hastalıkları ve Klinik Mikrobiyoloji Kliniği, Adana, Türkiye

${ }^{2}$ Çukurova Üniversitesi Tıp Fakültesi, Enfeksiyon Hastalıkları ve Klinik Mikrobiyoloji Anabilim Dalı, Adana, Türkiye

\section{Öz}

Amaç: Grip, dünyanın bütün bölgelerinde görülebilen, influenza virüsünün neden olduğu bir akut solunum yolu enfeksiyonudur. İfluenza ile enfekte olan hastalarda, hastaneye yatışı gerektiren ve ölüme yol açabilen komplikasyonlar gelişebilmektedir. Bu çalışmada 2015-2016 sezonundaki influenza epidemisi sırasında hastaların klinik ve virolojik bulgularının ve ağır hastalık açısından risk faktörlerinin değerlendirilmesi amaçlanmıştır.

Gereç ve Yöntem: İnfluenza benzeri hastalık tanısıyla, 2015-2016 influenza sezonunda hastanemizde yatırılarak takip edilen 284 hasta retrospektif olarak değerlendirildi. Nazofarengeal sürüntü örnekleri, Halk Sağlığı Laboratuvarında 21 farklı virüs açısından PCR ile test edildi.

Bulgular: İnfluenza benzeri hastalık tanısı ile yatırılarak takip edilen 284 hastanın 134'ü (\%47.2) erkek, 150'si (\%52.8) kadın ve yaş ortalaması 31.4 yı (0-91) idi. İnfluenza tanısı 175 (\%62) hastada virolojik olarak doğrulandı. İnfluenza virüslerinin 136'sı (\%78) H1N1; 30'u (\%17) H3N2; dokuzu (\%5) ise influenza B virüsü idi. H1N1 saptanan olguların 97'sinde (\%71.3); H3N2 saptanan olguların 15'inde (\%50); İnfluenza B saptananların dördünde (\%44.4) pnömoni ile uyumlu klinik ve/veya radyolojik bulgular mevcuttu. İleri yaştaki ( $\geq 65$ yaş) hastalarda mortalite istatistiksel olarak anlamlı derecede yüksekti ( $p=0.007)$.

Sonuç: Birinci basamak sağlık kurumları ile yürütülen sentinel sürveyansın yanında ulusal hastane bazlı sürveyansın yapılıyor olması hem influenza aktivitesinin izlenmesine hem de gerçek hastalık yükünün belirlenmesine katkı sağlayacaktır. Toplanan veriler hastalık kontrol önlemlerinin ve ulusal aşı politikalarının şekillenmesinde önemli rol oynayacaktır.

Anahtar Sözcükler: Mevsimsel influenza, hastane bazlı sürveyans, pnömoni.

\section{Abstract}

Aim: Influenza is an acute respiratory infection caused by influenza viruses which circulate in all parts of the world. Patients infected with influenza can develop complications that result in hospitalization and death. In this study, it has been aimed to interpret the clinical, virologic findings and risk factors for severe illness of the patients during 2015 2016 influenza epidemic.

Materials and Methods: The hospitalised 284 patients diagnosed with Influenza like illness during 2015-2016 influenza season, were evaluated retrospectively. Nasopharynegeal swab samples were tested for 21 different virus by PCR in Public Health Laboratory.

Results: Of the 284 patients hospitalized with the diagnose of Influenza like-illness, 134 (47.2\%) were male; 150 (52.8\%) were female and the median age was 31.4 (0-91) years. Clinical influenza diagnose was confirmed virologically in 175 patients. Influenza virus distribution was H1N1 in 136 (78\%) patients, H3N2 in 30 patients and Influenza $B$ in 9 (5\%) patients. Clinical and/or radiological findings consistent with pneumonia were present in 97 (71.3\%) of H1N1 cases, 15 (50\%) of H3N2 cases and 4 (44.4\%) of Influenza B cases. Mortality was statistically significantly higher in elderly ( $\geq 65$ years) patients $(p=0.007)$.

\footnotetext{
Yazışma Adresi: Ferit Kuşcu

Çukurova Üniversitesi Tıp Fakültesi, Enfeksiyon Hastalıkları ve

Klinik Mikrobiyoloji Anabilim Dalı, Adana, Türkiye

Makalenin Geliş Tarihi:25.02.2017 Kabul Tarihi: 09.03.2017
} 
Conclusion: Beside the sentinel surveillance which is conducted in the first-level health facilities, national hospital based surveillance practices will contribute both to follow-up the influenza activity and to determine the real disease burden. Collected data will play an important role in developing both disease control measures and national vaccination policies.

Keywords: Seasonal influenza, hospital-based surveillance, pneumonia.

\section{Giriş}

Grip, her yıl dünya nüfusunun \%5-20'sini etkileyen, özellikle risk gruplarında ciddi seyirli hastalığa ve ölümlere neden olabilen, geniş halk kitlelerini etkilediği için halk sağlığı açısından da özel önemi olan bir enfeksiyon hastalığıdır. Mevsimsel grip dünya çapında her yıl 3-5 milyon ağır hastalık tablosuna ve yaklaşık 250.000-500.000 ölüme yol açmaktadır. Aşılanma bu hastalıktan korunmak için bilinen en etkili yoldur (1). Ülkemizde grip aktivitesinin izlenmesi amacıyla 2005 yılından bu yana ayaktan başvuran hastalarda Ulusal Sentinel Sürveyans Ağı ile İnfluenza Benzeri Hastalık (İBH) sürveyansı yapılmaktadır. Ancak, birinci basamak sağlık kurumları ile yürütülen bu sentinel sürveyans, hastaneye yatışı gereken ağır influenza vakalarına ilişkin veri toplanması açısından yetersiz kalmaktadır $(2,3)$. Bu vakalardaki risk faktörlerinin saptanabilmesi, ağır hastalık açısından yüksek riskli grupların belirlenmesi, hastalığın şiddeti ve mortalitesi ile virus alt tipleri arasındaki ilişkinin değerlendirilebilmesi amacıyla 2015 yılında 5 pilot ilde Ağır Akut Solunum Yolu Enfeksiyonları (Severe Acute Respiratory Infections, SARI) sürveyansı başlatıldı. Hastanemiz SARI sürveyansının yürütüldüğü pilot hastanelerden biridir. Bu çalışmada, 2015-2016 sezonundaki influenza epidemisi sırasında influenza tanısı ile takip edilen hastaların klinik ve virolojik bulgularının, ağır hastalık açısından risk faktörlerinin retrospektif olarak değerlendirilmesi amaçlandı.

\section{Gereç ve Yöntem}

Hastanemize 14 Aralık 2015-1 Mart 2016 tarihleri arasındaki 10 haftalık sürede, İBH tablosu ile başvurup İnfluenza Vaka Yönetim Algoritmasına (4) göre yatırılarak takip edilen ve başka bir tanı ile hastanede yatmakta iken IBH tablosu ortaya çıkan hastalar çalışmaya dahil edildi. Hastalara ait demografik ve klinik veriler retrospektif olarak gözden geçirildi.

Her bir hasta için İnfluenza Vaka Bildirim Formu dolduruldu ve nazofarengeal veya boğaz sürüntü örnekleri alınarak virus taşıma vasatı ile Adana Halk Sağlığı Laboratuvarı'na gönderildi. Burada sürüntü örneklerinden RT-PCR ile 21 parametreli virus paneli çalışıldı (FTD Respiratory Pathogens 21. Fast Track Diagnostic, Luxembourg). Virolojik örnek alınan hastalara laboratuvar doğrulaması beklenmeden antiviral (oseltamivir 2x75 mg) tedavi başlandı.
Veriler SPSS 20. paket programı ile analiz edildi. Tanımlayıcı veriler yerine göre ortalama, standart sapma ve yüzde olarak belirtildi. Kategorik değişkenlerin karşılaştırılmasında ki-kare ve Fischer's Exact testleri uygulandı. Çalışma için Adana Numune Eğitim ve Araştırma Hastanesi Girişimsel Olmayan Çalışmalar Etik Kurul'undan onay alındı.

\section{Bulgular}

Influenza benzeri hastalık tanısı ile yatırılarak takip edilen 284 hastanın 134'ü (\%47.2) erkek, 150'si (\%52.8) kadın ve yaş ortalaması 31.4 yıl (0-91) idi. İnfluenza tanısı 175 (\%62) hastada virolojik olarak doğrulandı. Hastaların 136'sında (\%78) H1N1, 30'unda (\%17) H3N2, dokuzunda $(\% 5)$ ise influenza B virüsü saptandı. Örneklerde tespit edilen tüm viral etkenlerin dağılımı Tablo-1'de gösterilmiştir. H1N1 saptanan olguların 97'sinde (\%71.3), H3N2 saptanan olguların $15^{\prime}$ inde (\%50), Influenza B saptananların dördünde (\%44.4) pnömoni ile uyumlu klinik ve/veya radyolojik bulgular mevcuttu (Tablo-2). Çalışmaya dahil edilen 284 hastadan 232'sinde (\%81.7) ve virolojik olarak doğrulanan 175 hastanın 144'ünde (\%82.2) uç yaşlar (65 yaş üstü, 2 yaş altı), gebelik, diabetes mellitus, kalp yetmezliği, kronik böbrek yetmezliği, kronik obstrüktif akciğer hastalığı, malignite, obezite, steroid kullanımı, malnütrisyon gibi ağır hastalık açısından en az bir risk faktörü mevcuttu.

İfluenza benzeri hastalık tanısıyla hastaneye yatışı gereken hastaların 142'si (\%50), virolojik olarak influenza tanısı doğrulanan hastaların 95'i (\%54) 3-64 yaş aralığında idi. Şifa ile taburcu olan hastaların yaş ortalaması 29.2 yıl iken, ölen hastaların yaş ortalaması 53 yıl olarak saptandı $(p=0.007)$. Pnömoni tanısı alan hastaların 46'sı yoğun bakımda takip edildi ve bunlardan 25 'inde mekanik ventilasyon ihtiyacı oldu.

IBH tanısı ile yatırılan hastaların 46'sı öldü. Ölen hastaların etken virüs dağılımına bakıldığında 30'unda (\%65.2) H1N1, ikisinde (\%4.3) H3N2, üçünde (\%6.5) rhinovirus tespit edilirken, 11 hastada herhangi bir virüs saptanmadı. İnfluenza virüs alt tipleri mortalite açısından karşılaştırıldığında H1N1'in mortalitesi istatistiksel olarak anlamlı şekilde daha yüksekti $(p=0.04)$. İnfluenza tanısı virolojik olarak doğrulanmış ve ölen 32 hastadan yedisinde (\%21) bilinen bir risk faktörü yoktu.

Virolojik olarak doğrulanan 175 hastanın yaş grubuna göre mortalite oranlarına bakıldığında 65 yaş üstündeki 38 hastadan 14'ü (\%36.8), 3-64 yaş aralığındaki 95 hastadan 15 'i (\%15.8), 0-2 yaş aralığındaki 42 hastadan üçü (\%7.1) 
ex oldu. Altmış beş yaş üstü hastalardaki mortalite istatistiksel olarak anlamlı derecede yüksekti $(p=0.007)$. Hastanede yatmakta iken influenza semptomları ortaya çıkan ve virolojik olarak tanısı doğrulanan yedi hastada etken virüs $\mathrm{H} 1 \mathrm{~N} 1$ olarak saptandı. $\mathrm{Bu}$ hastalardan dördünde pnömoni tablosu gelişti ve üçü ex oldu.

İnfluenza için aşılanma durumu sorgulandığında 284 hastadan 162'si (\%57) aşılanmamış, 122 (\%43) hastanın ise aşılanma durumu bilinmiyor şeklinde kaydedilmişti

Tablo-1. Alınan Örneklerde Tespit Edilen Viral Etkenlerin Dağıımı.

\begin{tabular}{lrr}
\hline Virus & Sayı & $\%$ \\
\hline H1N1 & 136 & 47.9 \\
H3N2 & 30 & 10.6 \\
Influenza B & 9 & 3.1 \\
H1N1+Rhinovirus & 1 & 0.3 \\
RSV & 10 & 3.6 \\
Coronavirus & 6 & 2.1 \\
Human Metapneumovirus & 6 & 2.1 \\
Rhinovirus & 5 & 1.7 \\
Adenovirus & 2 & 0.8 \\
Coronavirus+RSV & 2 & 0.8 \\
Adenovirus+RSV & 1 & 0.3 \\
Parainfluenza virus & 1 & 0.3 \\
Negatif & 75 & 26.4 \\
TOPLAM & 284 & 100.0 \\
\hline
\end{tabular}

Epidemiyolojik açıdan ise, İBH tablosu ile hastanemize başvuran vakaların Aralık ayının 2.haftasından başlayarak giderek arttığı, Aralık ayının 4. haftasında ve Ocak ayının 4. haftasında iki ayrı pik yaptığı görüldü. On haftalık sürede İH tanısı ile hastanemizde takip edilen vaka sayılarının dağılımı Şekil-1'de gösterilmiştir.

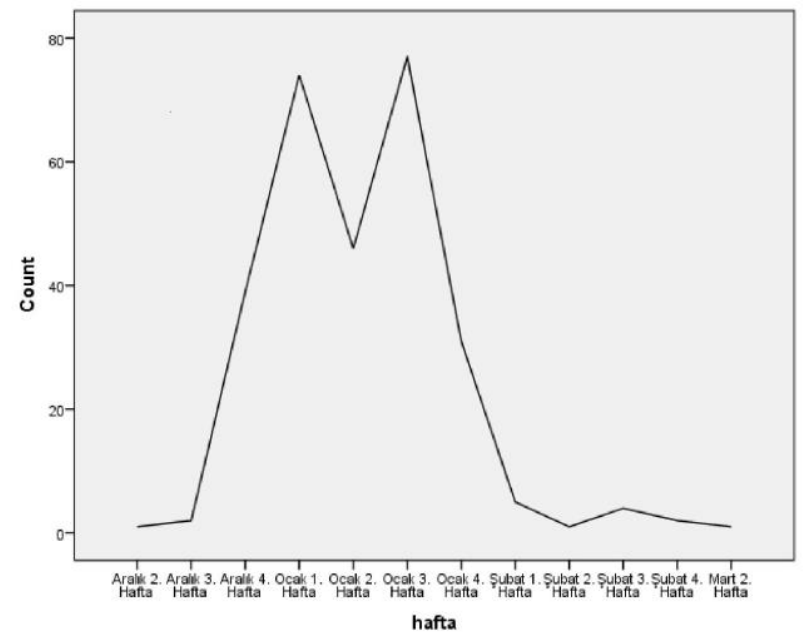

Şekil-1. 2015-2016 sezonunda haftalara göre influenza vaka sayıları.

Tablo-2. İnfluenza Virus Türlerinin, Yaş Gruplarına Göre Pnömoni Oranları ve Prognozları.

\begin{tabular}{|c|c|c|c|c|c|c|}
\hline VIRUS & & & $\begin{array}{c}0-2 \text { yaş } \\
\mathrm{n}, \%\end{array}$ & $\begin{array}{c}\text { 3-64 yaş } \\
n, \%\end{array}$ & $\begin{array}{c}65 \text { yaş } \\
n, \%\end{array}$ & Toplam (\%) \\
\hline \multirow{5}{*}{ H1N1 } & \multirow{2}{*}{ Pnömoni } & Var & $20(20.6)$ & 47 (48.5) & $30(30.9)$ & $97(100)$ \\
\hline & & Yok & $12(30.8)$ & $24(61.5)$ & $3(7.7)$ & 39 (100) \\
\hline & \multirow{3}{*}{ Prognoz } & Ex & $3(10.0)$ & $15(50)$ & $12(40)$ & 30 (100) \\
\hline & & Şifa & 29 & 54 & 21 & $104(100)$ \\
\hline & & Sevk & 0 & $2(100)$ & 0 & $2(100)$ \\
\hline \multirow{4}{*}{ H3N2 } & \multirow{2}{*}{ Pnömoni } & Var & 2 (13.3) & $9(60)$ & $4(26.7)$ & $15(100)$ \\
\hline & & Yok & 7 (46.7) & 7 (46.7) & $1(6.7)$ & $15(100)$ \\
\hline & \multirow[b]{2}{*}{ Prognoz } & Ex & 0 & 0 & $2(100)$ & $2(100)$ \\
\hline & & Şifa & 9 (32.1) & $16(57.1)$ & $3(10.7)$ & 28 (100) \\
\hline \multirow{4}{*}{ İnfluenza B } & \multirow{2}{*}{ Pnömoni } & Var & $1(25.0)$ & $3(75)$ & 0 & $4(100)$ \\
\hline & & Yok & 0 & $5(100)$ & 0 & $5(100)$ \\
\hline & \multirow{2}{*}{ Prognoz } & Ex & 0 & 0 & 0 & 0 \\
\hline & & Şifa & $1(11.1)$ & $8(88.9)$ & 0 & $9(100)$ \\
\hline
\end{tabular}

\section{Tartışma}

Mevsimsel grip genel olarak bilindiğinden çok daha fazla sayıda hastanede yatışa ve ölüme neden olmaktadır $(5,6)$. İnfluenza ve RSV'ye bağlı hastaneye yatışın araştırıldığı çalışmalarda RSV'ye bağlı yatışların yıldan yıla pek değişmezken, influenzaya bağlı yatışların dolaşımdaki virüs suşunun virülansına ve toplumdaki duyarlı popülasyonun oranına bağlı olarak sezondan sezona oldukça değişkenlik gösterdiği belirtilmektedir $(7,8)$. Son 2009 pandemisi öncesindeki döneme ait mevsimsel influenza epidemilerine ilişkin hastane bazlı ulusal veri oldukça kısıtıdır. Türkiye'nin de dahil olduğu dört farklı ülkeden 21 hastanenin verilerinin değerlendirildiği Global Influenza Hospital Surveillance Network (GIHSN) ile 2012-2013 
sezonunda ilk ulusal hastane bazlı sürveyans verileri elde edilmiştir (9).

GIHSN ile elde edilen hastane bazlı sürveyans verileri ışığında geriye dönük olarak ülkemizdeki son üç sezona bakıldığında 2012-2013 sezonunda baskın virüsün $\mathrm{H} 1 \mathrm{~N} 1$, yoğun bakıma yatış oranının \%30 ve mortalitenin \%19.4 olduğu; 2013-2014 sezonunda hastaların \% 79'unda H3N2 ve \%21'inde influenza B etken virüs iken hiç H1N1 saptanmadığı; 2014-2015 sezonunda ise baskın virüsün influenza B olduğu bildirilmiştir (3,9-11). Olgularımızda baskın virus H1N1 (\%78) olup, bunu H3N2 (\%17) ve influenza B (\%5) virüsleri izlemiştir. Buna göre, iki sezon aradan sonra H1N1'in yeniden baskın virüs olarak dolaşımda olduğu görülmektedir. Çalışmamızda etken virüsün H1N1 olduğu olguların \%71.3'ünde hastalığın pnömoni tablosu ile seyretmesi ve ölen hastaların \%65.2'sinde saptanan virüsün H1N1 olması, H1N1 ile oluşan enfeksiyonlarda pnömoni ve mortalite oranlarının diğer virüs alt tiplerine göre oldukça yüksek olduğunu göstermektedir. Bulgularımıza paralel şekilde, ülkemizin de içinde bulunduğu dokuz ülkeden 29 merkezin verilerinin değerlendirildiği GIHSN 2015-2016 raporunda H1N1'in baskın virus olduğu; H1N1 virus alt tipinin yoğun bakım-da yatış, pnömöni, mekanik ventilasyon gereksinimi ve mortalite ile ilişkili olduğu bildirilmiştir (12).

İnfluenzanın belirli risk gruplarında ciddi pnömoni tablosuyla ve mortal seyredebildiği ve bu hastalar için en etkili korunma yönteminin her yıl aşılanmak olduğu bilinmektedir $(13,14,15)$. Bizim hastalarımız risk faktörleri açısından sorgulandığında, IBH tanısıyla yatırılan hastaların \%81.7'sinde ve virolojik olarak doğrulanan hastaların \%82.2'ünde ağır hastalık açısından en az bir risk faktörünü mevcut olmasına rağmen önemli bir kısmı aşılanmamıştı. Ülkemizdeki riskli grupların prevalansı, bunların aşılanma durumu ve aşılanmaya etki eden faktörlerin araştırıldığı bir çalışmada, Sağlık Bakanlığı tarafından 65 yaş üstündeki kişilere ve risk grubundaki hastalara her yıl grip aşısı yapılması önerilmesine ve aşının geri ödemesinin olmasına rağmen halen aşılanma oranlarının oldukça düşük olduğu bildirilmiştir (16).

Yaş gruplarına göre verilerin analiz edildiği bir çalışmada, dolaşımdaki genel virüs alt tipinin, farklı yaş gruplarındaki dağılımı yansıtmayabileceği, klinik tablo, eşlik eden hastalık, hastaneye ya da yoğun bakıma yatış gereksinimi, mortalite, aşının etkinliği gibi özelliklerin yaş grupları arasında farklılık gösterebileceği belirtilmiş ve bu durumun kontrol önlemleri açısından hedef yaş gruplarının belirlenmesindeki önemi vurgulanmıştır (17). Bulgularımız, influenzanın tüm yaş gruplarında görülmekle birlikte, en çok 3-64 yaş grubunun etkilendiğini ancak yaş grubuna göre ölüm oranlarına bakıldığında 65 yaşın üstündeki hastalarda mortalitenin en yüksek (\%36.8) olduğunu göstermektedir. Genel olarak bakıldığında, ölen hastaların yaş ortalaması 53 yıl iken, şifa ile taburcu olanların yaş ortalamasının 29.2 yıl olması yine ileri yaşın ağır hastalık açısından riskli bir grup olduğunu ortaya koymaktadır. 2009 pandemisi sonrasında yapılan seroprevalans çalışmaları, özellikle 65 yaş üstündeki kişiler olmak üzere halen $\mathrm{H} 1 \mathrm{~N} 1$ 'e duyarlı olan bir popülasyonun olduğunu göstermiştir $(18,19)$. Bizim hastalarımızda da baskın virüsün $\mathrm{H} 1 \mathrm{~N} 1$ olması bu duyarlıı̆̆ın devam ettiğini göstermektedir.

Çalışmamızda, hastanede yatmakta iken IBH tablosu gelişen ve virolojik olarak tanısı doğrulanan yedi hasta viral hastane enfeksiyonu olarak değerlendirildi. Bu durum, grip sezonu süresince viral hastane enfeksiyonu açısından hastaların sıkı takip edilmesi gerektiğini vurgulamaktadır. Kapsamlı bir çalışmada, viral hastane enfeksiyonunun genel insidansının \%3.9 olduğu, influenza virüslerinin rhinovirustan sonra ikinci sırada yer aldığı belirtilmiştir (20)

Hastanemize 2015-2016 sezonundaki 10 haftalık sürede IBH tablosu ile başvurup yatışı yapılan vaka sayılarının Aralık ayının ikinci haftasından başlayarak giderek arttığı, Aralık ayının dördüncü haftasında birinci pik ve Ocak ayının dördüncü haftasında ikinci bir pik yaptığı tespit edildi. Çalışmanın son dört haftasında H3N2 ve influenza $B$ virüsleri izole edilmeye başlansa da on hafta-lık süre boyunca H1N1 hakimiyetinin devam ettiği görül-dü. Hastane bazlı sürveyans verilerimize benzer şekilde, Türkiye Halk Sağlığı Kurumu'nun 2015 sezonu sentinel sürveyans verilerine bakıldığında Aralık ayının ikinci haftasında \%6 olan influenza pozitiflik oranının dördüncü haftaya gelindiğinde \%38.2'lere çıktığı görülmektedir (21). Ülkemizden SARI sürveyansı yapan bir başka merkezde de bulgularımıza paralel şekilde, en sık izole edilen H1N1 virus alt tipinin, yoğun bakım intiyacı ve mortalite ile anlamlı ilişkisi olduğu belirtilmektedir (22).

Çalışmamız, sadece tek bir merkezin verilerini içermesi nedeniyle hastalığın ülkemizdeki genel durumunu yansıtmaması, kayıtlarda bütün hastaların aşılanma durumuna ulaşılamadığı için aşılanma oranlarının tam bilinmemesi, semptomların başlaması ile antiviral uygulanması arasındaki süre bütün hastalarda belirlenemediği için oseltamivinin etkinliği açısından değerlendirme yapılamaması gibi kısıtılıklara sahipti.

\section{Sonuç}

$\mathrm{Bu}$ hastane bazlı sürveyansın sonuçları, influenzanın sadece pandemi dönemlerinde değil, mevsimsel salgınlarda da önemli bir mortalite nedeni olabileceğini ortaya koymaktadır. Birinci basamak sağlık kurumları ile yürütülen sentinel sürveyansın yanında, ulusal hastane bazlı sürveyansın başlatılmış olması, hem influenza aktivitesinin daha etkin bir biçimde izlenmesine hem de gerçek hastalık yükünün belirlenmesine katkı sağlayarak hastalık kontrol önlemlerinin ve ulusal aşı politikalarının şekillenmesinde önemli rol oynayacaktır. 


\section{Kaynaklar}

1. Influenza (Seasonal), Fact sheet [homepage on the Internet]. World Health Organization [updated November 2016; cited 20 February 2016]. Available from: http://www.who.int/mediacentre/factsheets/fs211/en/

2. Ciblak MA, Tütenyurd MK, Asar S, Tulunoğlu M, Fındıkçı N, Badur S. 2003-2012 Yıllarını Kapsayan Dokuz Sezonda Grip Sürveyansı Bulguları: İstanbul Tıp Fakültesi Ulusal İnfluenza Referans Laboratuvarı Sonuçları. Mikrobiyoloji Bülteni 2012 46(4): 575-593.

3. Puig-Barber J, Tormos A, Trushakova S, et al. The Global Influenza Hospital Surveillance Network (GIHSN): A new platform to describe the epidemiology of severe influenza. Influenza Other Respir Viruses 2015; 21. doi: 10.1111/irv.12335.

4. İnfluenza Vaka Yönetim Algoritması [homepage on the Internet]. Türkiye Halk Sağlığı Kurumu [cited 21 February 2016]. Available from: http://grip.gov.tr/saglik-personeli-icin-bilgiler/282-influenza-vaka-yonetim-algoritmasi.html

5. Ortiz JR, Neuzil KM, Shay DK, et al. The burden of influenza-associated critical illness hospitalizations. Crit Care Med 2014;42(11):2325-32.

6. Ortiz JR, Neuzil KM, Cooke CR, Neradilek MB, Goss CH, Shay DK. Influenza pneumonia surveillance among hospitalized adults may underestimate the burden of severe influenza disease. PLoS One 201425;9(11):e113903.

7. Zhou H, Thompson WW, Viboud CG, et al. Hospitalizations associated with influenza and respiratory syncytial virus in the United States, 1993-2008. Clin Infect Dis 2012;54(10):1427-36.

8. Chaves SS, Aragon D, Bennett N, et al. Patients hospitalized with laboratory-confirmed influenza during the 2010-2011 influenza season: Exploring disease severity by virus type and subtype. J Infect Dis 2013;208(8):1305-14.

9. Puig-Barberà J, Tormos A, Sominina A, et al. First-year results of the Global Influenza Hospital Surveillance Network: 20122013 Northern hemisphere influenza season. BMC Public Health 2014;5(14):564.

10. Puig-Barberà J, Natividad-Sancho A, Trushakova S, et al. Global Influenza Hospital Surveillance Study Group. Epidemiology of hospital admissions with influenza during the 2013/2014 northern hemisphere influenza season: Results from the global influenza hospital surveillance network. PLoS One 2016;19(11):5.

11. Puig-Barberà J, Burtseva $\mathrm{E}, \mathrm{Yu} \mathrm{H}$, et al. Influenza epidemiology and influenza vaccine effectiveness during the 2014-2015 season: Annual report from the Global Influenza Hospital Surveillance Network. BMC Public Health 2016;16(Suppl 1):757.

12. Summary of the 2015-2016 Season Results [homepage on the Internet]. Global Influenza Hospital Surveillance Report [cited 21 February 2016]. Available from: $h$ ttp://gihsn.org/?page=result\&id=2015-2016.

13. Mullooly JP, Bridges CB, Thompson WW, et al. Influenza- and RSV-associated hospitalizations among adults. Vaccine 2007;25(5):846-55.

14. Ono $\mathrm{S}$, Ono $\mathrm{Y}$, Matsui $\mathrm{H}$, Yasunaga $\mathrm{H}$. Factors associated with hospitalization for seasonal influenza in a Japanese nonelderly cohort. BMC Public Health 2016; 2(16):922.

15. Loubet $P$, Samih-Lenzi N, Galtier F, et al. Factors associated with poor outcomes among adults hospitalized for influenza in France: A three-year prospective multicenter study. J Clin Virol 2016;79(1):68-73.

16. Ciblak MA, Grip Platformu. Influenza vaccination in Turkey: Prevalence of risk groups, current vaccination status, factors influencing vaccine uptake and steps taken to increase vaccination rate. Vaccine. 2013;31(3):518-23.

17. Beauté J, Zucs P, Korsun N, et al. European Influenza Surveillance Network. Age-specific differences in influenza virus type and subtype distribution in the 2012/2013 season in 12 European countries. Epidemiol Infect 2015t;143(14):2950-8.

18. Gözalan A, Altaş AB, Sevencan F, et al. Seroprevalence following the first wave of pandemic influenza A (H1N1) in Turkey, 2009. Jpn J Infect Dis 2012;65(1):13-8.

19. Çifci A, Erol Ö, Cesur S, Aksoy N, Kisa Ü. The comparison of pandemic HIN1 IgG levels between HIN1 influenza-vaccinated healthcare workers and unvaccinated healthcare workers. Turk J Med Sci 2014;44(6):1047-50.

20. Choi HS, Kim MN, Sung H, et al. Laboratory-based surveillance of hospital-acquired respiratory virus infection in a tertiary care hospital. Am J Infect Control 2017;45(5):e45-e4.

21. Haftalık İnfluenza Sürveyans Raporu 2015-2016 [homepage on the Internet]. Türkiye Halk Sağlığı Kurumu [cited 21 February 2016]. Available from: http://www.grip.gov.tr/saglik-personeli-icin-bilgiler/283-haftalik-influenza-surveyans-raporu-2.

22. Eser FC, Solay AH, Altın N, et al. Ciddi alt solunum yolu enfeksiyonu tanısı ile yatarak takip edilen hastalarda etken virüslerin belirlenmesi. Mediterr J Infect Microb Antimicrob 2016;6(Supplement 1). 